Egyptian Journal of Aquatic Biology \& Fisheries

Zoology Department, Faculty of Science,

Ain Shams University, Cairo, Egypt.

ISSN $1110-6131$

Vol. 24(7): 427 - 440 (2020)

www.ejabf.journals.ekb.eg

\title{
Gut colonization and permanence of the probiotics in Labeo calbasu (Hamilton, 1822)
}

\author{
Oshin Dhillon $^{1,2}$ and Anita Bhatnagar ${ }^{1, *}$ \\ ${ }^{1}$ Department of Zoology, Kurukshetra University, Kurukshetra, India \\ ${ }^{2}$ Department of Zoology, Akal University, Bathinda, India \\ *Corresponding Author: anitabhatnagar@gmail.com
}

\section{ARTICLE INFO \\ Article History: \\ Received: Sept. 15, 2020 \\ Accepted: Oct. 31, 2020 \\ Online: Nov. 27, 2020}

Keywords:

Aneurinibacillus

aneurinilyticus,

immunohistochemistry,

gut microflora,

Labeo calbasu,

probiotics

\section{ABSTRACT}

The gnotobiotic approach utilizing autochthonous probiotics enhance the growth and immunity by fastening to persist in the fish's gastrointestinal tract. The present work was conducted to examine the adherence and colonization of probiotic, Aneurinibacillus aneurinilyticus and Stenotrophomonas sp. fed to Labeo calbasu. The juveniles were fed on Diet C (control), Diet 1 (A. aneurinilyticus), Diet 2 (Stenotrophomonas sp.) and Diet 3 (A. aneurinilyticus and Stenotrophomonas sp.) maintained in triplicate with ten individuals each for a duration of 90 days. The fingerlings depicting significant growth performance $(p<0.05)$ were subjected to intestinal enzymatic, haematological and immunohistochemical assays. Diet 1 fed group revealed significantly $(p<0.05)$ high values of enzymes, blood corpuscles and respiratory burst activity. The results showed the permanence of probiotic colonies in gastrointestinal tract lumen and on the microvilli edges. This clearly reveals that probiotic A. aneurinilyticus enhanced growth, digestibility and immune response providing an appreciable approach towards sustainable aquaculture.

\section{INTRODUCTION}

Intensification of aquaculture requires effective fish management and culture practices for appeasing the consistently expanding need of developing populace. The requirement for upgraded disease resistance, feed proficiency, and growth development of cultured organisms are significant for different divisions of this industry. Probiotics could be presented in commercial aquaculture by consolidating them into formulated fish diets or in the form of bacteria biofilm to accomplish colonization in the fish gastrointestinal (GI) tract at a higher degree. These tiny organisms may be helpful in diminishing the occurrence of ailment or decreasing the seriousness of outbreaks. Establishment of defensive gut microflora is a key segment in barring potential trespassers and looking after wellbeing and maintaining health. Symbiotic bacteria assist in digestion, absorption and consumption of food by the production of various enzymes (Carnevali et al., 2006). This prompts the utilization of probiotics to avert infection hazard and provide immune-stimulation in the candidate species. 
Distinctive scrutinizations have demonstrated the probiotic's incorporation to enhance the growth efficiency, weight gain and efficient conversion of feed into flesh in fish (Wang et al., 2008; Son et al., 2009; Daniels et al., 2010; Bisht et al., 2012; Bhatnagar and Raparia, 2014; Bhatnagar and Lamba, 2017; Bhatnagar and Dhillon, 2019). The wellbeing status of fishes is interestingly identified with their prompt surroundings that comprise a high convergence of microorganisms. Gatesoupe (1999) stated that probiotics aid in maintaining the health and wellness of the host organism by contributing to gut microbiota. These are ought to adhere well to the intestinal tract or develop sufficiently quick so as to remain within the host gut to prevent their removed with food's movement in gastrointestinal tract. Probiotics can expand their time inside the gut in this way impacting the gastrointestinal microflora of their host by attaching to the intestinal mucosa (Vine et al., 2004). The antagonistic activity against the diseasecausing organisms is known to be enhanced by the colonization of probiotics to the gut of host (Coconnier et al., 2003).

The permanence and colonization of the probiotic in the gut can be visualized by the means of microscopy techniques (Salinas et al., 2008). Thus, using the technique of immunohistochemistry, the present study aimed to address the ability of the supplemented probiotics enhancing the growth, intestinal enzymatic activity and immune response by adhering and making a permanence colonization in the gastrointestinal tract of Labeo calbasu juveniles.

\section{MATERIALS AND METHODS}

The present study had the same experimental set up as described by Bhatnagar and Dhillon (2019) with four experimental feeds (Diet C, Diet 1, Diet 2, and Diet 3) containing probiotic bacterial strains isolated from the gut of L. calbasu, Aneurinibacillus aneurinilyticus, and Stenotrophomonas sp. The fingerlings (initial weight 3.01-3.05 g) were fed with the respective pelleted feed twice daily (4\% body weight) for 90 days. Ration was adjusted by weighing the fingerlings fortnightly using top pan balance (AFCOSET FX-1200) and water was renewed daily with dechlorinated water $\left(25 \pm 1^{\circ} \mathrm{C}\right)$. Weight gain was measured (Garg et al., 2002). The juveniles were analysed for intestinal enzymatic activity, haematological diagnosis and respiratory burst activity at the end of 90 days feeding experiment. A challenge trial was also conducted at the end where ten fingerlings from each treatment were challenged with fish pathogenic strain Aeromonas hydrophila (MTCC 1739) (Austin et al., 1995) following standard safety measures while handling and discarding bacteria (Christian, 2007).

\section{Determination of intestinal enzymatic activity}

Intestinal protease, amylase and cellulase activities were determined by following the standard procedures given by Walter (1984), Sawhney and Singh (2000) and Sadasivam and Manickam (1996), respectively, by processing intestine of few fingerlings from each feeding group. Specific enzymatic activities were calculated as follows:

Specific protease activity (mg of tyrosine mg $\operatorname{protein}^{-1} \mathrm{~h}^{-1}$ )

$$
=\frac{\text { Enzyme activity }\left(\mathrm{mg} \mathrm{g}^{-1} \mathrm{~h}^{-1}\right)}{\text { Protein } \mathrm{mg} \mathrm{g}^{-1}}
$$


Specific amylase activity (mg of maltose mg protein ${ }^{-1} \mathrm{~h}^{-1}$ )

$$
=\frac{\text { Enzyme activity }\left(\mathrm{mg} \mathrm{g}^{-1} \mathrm{~h}^{-1}\right)}{\text { Protein } \mathrm{mg} \mathrm{g}^{-1}}
$$

Specific cellulase activity ( $\mathrm{mg}$ of glucose $\mathrm{mg}_{\text {protein }}{ }^{-1} \mathrm{~h}^{-1}$ )

$$
=\frac{\text { Enzyme activity }\left(\mathrm{mg} \mathrm{g}^{-1} \mathrm{~h}^{-1}\right)}{\text { Protein } \mathrm{mg} \mathrm{g}^{-1}}
$$

\section{Haematological diagnosis}

To study the changes in profile of different hematological and immunological parameters, the blood sample was collected in vacutainers. Total erythrocyte and leucocyte count, before and after the challenge was done using hemocytometer and Neubaur's counting chamber by standard protocol of Dacie and Lewis (1971).

TEC $=$ total number of cells in five small squares $\times 10000 \mathrm{~mm}^{-3}$

TLC $=$ Total number of cells in four large squares $\times 500 \mathrm{~mm}^{-3}$

The phagocytic assay was performed according to the method of Siwicki et al. (1994) and Park and Jeong (1996). Phagocytic ratio (PR) and phagocytic index (PI) were determined by enumerating 100 phagocytes per slide under a microscope and average of three slides was calculated.

Phagocytic ratio(PR; i.e.percentage of cell with engulfed bacteria)

$$
=\frac{\text { Number of phagocytic cells with engulfed bacteria }}{\text { Number of phagocytic cells }} \times 100
$$

Phagocytic Index(PI; i.e. number of engulfed bacteria per cell)

$$
=\frac{\text { Number of engulfed bacteria }}{\text { Number of phagocytic cells }} \times 100
$$

The respiratory burst activity is the production of oxygen radical production by blood phagocytes. It was measured by recording the light absorption of the sample at wavelength of $540 \mathrm{~nm}$ spectrophotometrically by nitroblue tetrazolium (NBT) assay (Anderson and Siwicki, 1995) after the challenge trial with A. hydrophila.

\section{Immunohistochemical analysis}

The feeding group showing significant result were further considered for histological study of intestine. The tissue was fixed in Bouin's fixative and was further processed with different alcohol grades (Pearse, 1968). Thin section $(5 \mu \mathrm{m})$ cutting was done with rotary microtome. The eosin-haematoxylin stained tissue was examined for histology under light microscope.

The existence of the probiotic supplemented through the fish feed was perused by the immunohistochemical analysis of intestinal cross-sections. The intestine samples of the fish with best results after the feeding trial were placed for fixation in $10 \%$ formalin. The tissue pieces were then dehydrated by immersing in different grades of alcohol to avoid contortion. Tissue was not placed in paraffin and $5 \mu \mathrm{m}$ cuts were made after a treatment with 3\% 3-aminopropylethoxysilane (Sigma Laboratories). Tissue dewaxing was done at $60^{\circ} \mathrm{C}$ followed by xylol washing thrice. Soaking of the tissue was done with $10 \%$ alcohol following twice washing with $70 \%$ and a final wash with deionised water. Immunodetection was carried out following the manufacturer's instructions by Immuno Cruz Staining System (Santa Cruz Biotechnology, USA). Bacillus Spore Antigen Polyclonal Antibody (Invitrogen PA1-7203) at a 1:20 dilution (Affinity Bioreagents, USA) was employed as primary antibody with Grill's haematoxylin as a contrast 
medium. The tissue was then observed and photographed at $\times 400$ under Leica DM 6000 microscope fitted with Leica DFC 480C camera (Leica, Germany) using a dark contrast for better visibility of the images.

\section{Statistical analysis}

One Way Analysis of variance (ANOVA) followed by Duncan's multiple range tests (Duncan, 1955) was used for analysing the significant differences among treatment groups. Statistical significance was settled at a probability value of $p<0.05$. All statistics were performed using SPSS Version 18.0

\section{RESULTS}

The fingerlings sufficiently acknowledged the trial diet and kept up normal conduct all through the experimental frame without any mortality for all dietary treatments. ANOVA followed by Duncan's Multiple Range Test revealed Diet 1 fed group consolidated with probiotic Aneurinibacillus aneurinilyticus with significantly high growth of fish in terms of weight gain $(p<0.05)$.

\section{Intestinal digestive enzyme activities}

The intestinal enzymatic activity was observed to be significantly $(p<0.05)$ high in the probiotic supplemented groups as compared to control (without probiotic incorporation). The fingerlings in Diet 1 fed group (supplemented with $A$. aneurinilyticus) manifested significantly $(p<0.05)$ high specific protease $(2.96 \pm 0.018$ $\mathrm{mg}$ of tyrosine liberated $\mathrm{mg}$ of protein $\left.{ }^{-1} \mathrm{~h}^{-1}\right)$, specific amylase $(1.79 \pm 0.009 \mathrm{mg}$ of maltose liberated $\mathrm{mg}$ of protein $\left.{ }^{-1} \mathrm{~h}^{-1}\right)$ and specific cellulase $(2.62 \pm 0.009 \mathrm{mg}$ of glucose liberated $\mathrm{mg}$ of protein ${ }^{-1} \mathrm{~h}^{-1}$ ) (Table 1).

\section{Haematological parameters}

Blood samples were collected for haematological diagnosis reporting erythrocyte and total leucocyte count (TEC and TLC) of $L$. calbasu fingerlings fed with different dietary feeds (Figure 1, Table 2). Significant $(p<0.05)$ increase in TEC $\left(10^{6} \mathrm{~mm}^{-3}\right)$ and TLC $\left(10^{3} \mathrm{~mm}^{-3}\right)$ was observed in the fingerlings fed with probiotic supplemented dietary feed as to the fingerlings group fed with Diet C $(2.14 \pm 0.044$ and $43.83 \pm 0.145)$. Phagocytic ratios and phagocytic indices in the fingerlings fed with various selected strain of probiotics were significantly $(\mathrm{p}<0.05)$ higher than control fingerlings during the assay period. Maximum values of phagocytic ratio $(82.38 \pm 1.097 \%)$ and phagocytic index $(2.03 \pm 0.033)$ were observed in Diet 1 fed group (Table 2). After challenge trial, the haematological values were slightly lower for TEC and higher for TLC than prechallenge values depicting a possible expanded contagiousness and provocative response intervened by leucocyte, being highest for Diet 1 juveniles with significant difference among groups $(p<0.05)$. The intracellular superoxide radicals produced by leucocytes in response to the pathogens was restrained by the reduction of Nitroblue tetrazolium (NBT) and was perceived to be significantly influenced by the probiotic diets. The statistical analysis resulted in significant $\left(p<0.05\right.$ ) variation in the NBT activity (Units $\mathrm{min}^{-1} \mathrm{mg}^{-1}$ of protein) with superlative increase to be observed in $A$. aneurinilyticus supplemented fingerlings $(0.58 \pm 0.015)$ (Figure 2$)$. 


\section{Colonization and permanence of Aneurinibacillus aneurinilyticus strain in $L$. calbasu by immunohistochemical analysis}

The fingerlings fed with Diet 1 incorporated with gram positive probiotic $A$. aneurinilyticus showed significantly high growth, intestinal enzymatic activity and immune response. The results of the histological studies displayed conventional framework of intestine with circular muscles, longitudinal muscles, serosa, villi and microvilli. To observe the presence of colonization and permanence of the incorporated probiotics through feed, the gastrointestinal tissue of the fingerlings was analysed by immunohistochemical analysis. The existence of the probiotic augmented to the juveniles was contemplated in Bacillus Spore Antigen Polyclonal Antibody (Invitrogen PA1-7203) labelled histological cuts in the gastrointestinal lumen and on the microvilli edges with positive marking and fluorescence delineated the ubeity of probiotic colonies when visualized under fluorescent microscope (Figure 3).

Table 1: Growth and the intestinal enzyme activities of Labeo calbasu fed on the diets containing autochthonous probiotic bacterial strain (Diet $\mathbf{C}=\mathrm{Control}$, Diet $\mathbf{1}=$ A. aneurinilyticus, Diet $2=$ Stenotrophomonas sp., Diet $3=A$. aneurinilyticus + Stenotrophomonas sp.)

\begin{tabular}{|c|c|c|c|c|}
\hline Growth parameters & $\begin{array}{c}\text { Diet C } \\
\text { (Control) }\end{array}$ & $\begin{array}{c}\text { Diet } 1 \\
(A . \\
\text { aneurinilyticus })\end{array}$ & $\begin{array}{c}\text { Diet } 2 \\
\text { (Stenotrophomonas } \\
\text { sp.) }\end{array}$ & $\begin{array}{c}\text { Diet } 3 \\
\text { (A. aneurinilyticus }+ \\
\text { Stenotrophomonas } \\
\text { sp.) }\end{array}$ \\
\hline Initial weight (g) & $3.01 \pm 0.018^{\mathrm{A}}$ & $3.05 \pm 0.015^{\mathrm{A}}$ & $3.03 \pm 0.017^{\mathrm{A}}$ & $3.05 \pm 0.009^{\mathrm{A}}$ \\
\hline Final weight (g) & $4.49 \pm 0.022^{\mathrm{D}}$ & $5.42 \pm 0.038^{\mathrm{A}}$ & $4.93 \pm 0.023^{\mathrm{C}}$ & $5.11 \pm 0.015^{\mathrm{B}}$ \\
\hline Weight gain (g) & $1.48 \pm 0.032^{\mathrm{D}}$ & $2.36 \pm 0.023^{\mathrm{A}}$ & $1.90 \pm 0.019^{C}$ & $2.06 \pm 0.009^{\mathrm{B}}$ \\
\hline Survival rate $(\%)$ & 100 & 100 & 100 & 100 \\
\hline $\begin{array}{l}\text { Specific protease } \\
\text { activity }^{1}\end{array}$ & $2.27 \pm 0.014^{\mathrm{D}}$ & $2.96 \pm 0.018^{\mathrm{A}}$ & $2.51 \pm 0.014^{\mathrm{C}}$ & $2.67 \pm 0.014^{\mathrm{B}}$ \\
\hline $\begin{array}{l}\text { Specific amylase } \\
\text { activity }^{2}\end{array}$ & $1.60 \pm 0.014^{\mathrm{D}}$ & $1.79 \pm 0.009^{\mathrm{A}}$ & $1.71 \pm 0.009^{\mathrm{C}}$ & $1.76 \pm 0.009^{\mathrm{B}}$ \\
\hline $\begin{array}{l}\text { Specific cellulase } \\
\text { activity }^{3}\end{array}$ & $2.09 \pm 0.012^{\mathrm{D}}$ & $2.62 \pm 0.009^{\mathrm{A}}$ & $2.46 \pm 0.012^{\mathrm{C}}$ & $2.54 \pm 0.009^{\mathrm{B}}$ \\
\hline
\end{tabular}

All the values are Mean \pm S.E.M.

Means with different letters in the same row are significant $(p<0.05)$ different.

(Data were analysed by Duncan's Multiple Range Test)

${ }^{1} \mathrm{mg}$ of tyrosine liberated $\mathrm{mg}$ of protein ${ }^{-1} \mathrm{~h}^{-1}$

${ }^{2} \mathrm{mg}$ of maltose liberated $\mathrm{mg}$ of protein ${ }^{-1} \mathrm{~h}^{-1}$

${ }^{3} \mathrm{mg}$ of glucose liberated $\mathrm{mg}$ of protein ${ }^{-1} \mathrm{~h}^{-1}$ 


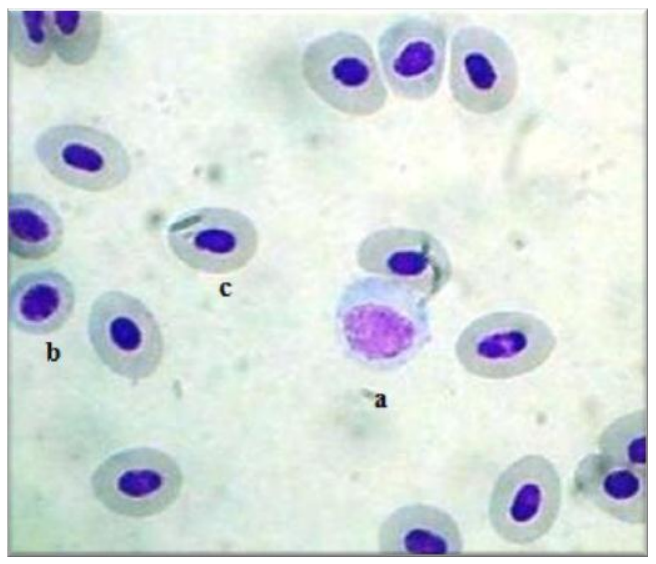

Figure 1: Lymphocyte (a), monocytes (b) and erythrocyte (c) of Labeo calbasu observed in different dietary treatments with probiotics $(\times 1000)$.

Table 2: Haematological values, phagocytic ratio and phagocytic index of Labeo calbasu fed on diets containing autochthonous probiotic bacterial strain (Diet $\mathrm{C}=$ Control, Diet 1= A. aneurinilyticus, Diet 2= Stenotrophomonas sp., Diet 3=A. aneurinilyticus + Stenotrophomonas sp.)

\begin{tabular}{|c|c|c|c|c|}
\hline $\begin{array}{c}\text { Haematological } \\
\text { Parameters }\end{array}$ & $\begin{array}{c}\text { Diet C } \\
\text { (Control) }\end{array}$ & $\begin{array}{c}\text { Diet } 1 \\
(A . \\
\text { aneurinilyticus })\end{array}$ & $\begin{array}{c}\text { Diet } 2 \\
\text { (Stenotrophomonas } \\
\text { sp.) }\end{array}$ & $\begin{array}{c}\text { Diet } 3 \\
\text { (A. aneurinilyticus } \\
+ \\
\text { Stenotrophomonas } \\
\text { sp.) }\end{array}$ \\
\hline \multicolumn{5}{|c|}{ TEC $^{*}\left(\mathbf{x 1 0}^{6} \mathrm{~mm}^{-3}\right)$} \\
\hline Pre-Challenge & $2.14 \pm 0.044^{\mathrm{C}}$ & $2.75 \pm 0.017^{\mathrm{A}}$ & $2.53 \pm 0.023^{\mathrm{B}}$ & $2.60 \pm 0.018^{B}$ \\
\hline Post Challenge & $1.48 \pm 0.023^{\mathrm{C}}$ & $2.31 \pm 0.035^{\mathrm{A}}$ & $2.08 \pm 0.233^{\mathrm{B}}$ & $2.16 \pm 0.012^{\mathrm{B}}$ \\
\hline \multicolumn{5}{|c|}{ 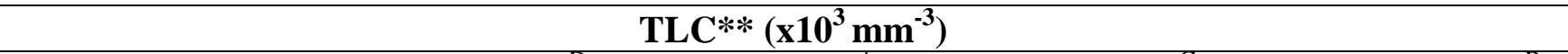 } \\
\hline Pre-Challenge & $43.83 \pm 0.145^{\mathrm{D}}$ & $52.63 \pm 0.233^{A}$ & $48.63 \pm 0.318^{C}$ & $50.73 \pm 0.202^{\mathrm{B}}$ \\
\hline Post Challenge & $47.83 \pm 0.223^{\mathrm{D}}$ & $55.10 \pm 0.173^{\mathrm{A}}$ & $50.73 \pm 0.437^{\mathrm{C}}$ & $52.97 \pm 0.120^{\mathrm{B}}$ \\
\hline \multicolumn{5}{|c|}{ Phagocytic assay } \\
\hline $\begin{array}{l}\text { Phagocytic } \\
\text { Ratio (\%) }\end{array}$ & $55.96 \pm 1.586^{\mathrm{D}}$ & $82.38 \pm 1.097^{\mathrm{A}}$ & $60.21 \pm 0.373^{\mathrm{C}}$ & $65.97 \pm 0.944^{\mathrm{B}}$ \\
\hline $\begin{array}{l}\text { Phagocytic } \\
\text { Index }\end{array}$ & $1.25 \pm 0.041^{\mathrm{D}}$ & $2.03 \pm 0.033^{\mathrm{A}}$ & $1.39 \pm 0.019^{\mathrm{C}}$ & $1.60 \pm 0.012^{\mathrm{B}}$ \\
\hline
\end{tabular}

*TEC- Total Erythrocyte Count

**TLC- Total Leucocyte Count

All values are Mean \pm S.E.M.

Means with different letters in the same row are significantly $(p<0.05)$ different (Duncan's Multiple Range test). 


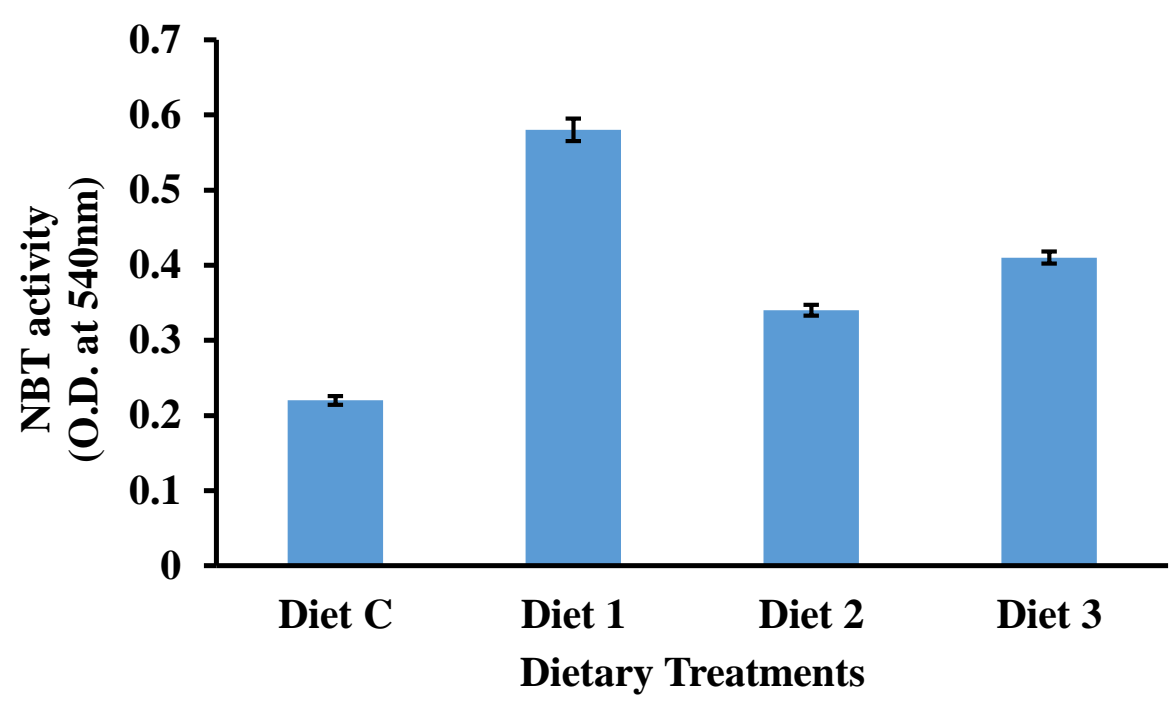

Figure 2: Nitroblue tetrazolium (NBT) activity (O.D. at $540 \mathrm{~nm}$ ) of Labeo calbasu fed on diets containing autochthonous probiotic strain in a challenge trial with Aeromonas hydrophila for 10 days (Diet $\mathrm{C}=\mathrm{Control}$, Diet $1=A$. aneurinilyticus, Diet 2= Stenotrophomonas sp., Diet 3= A. aneurinilyticus + Stenotrophomonas sp.)

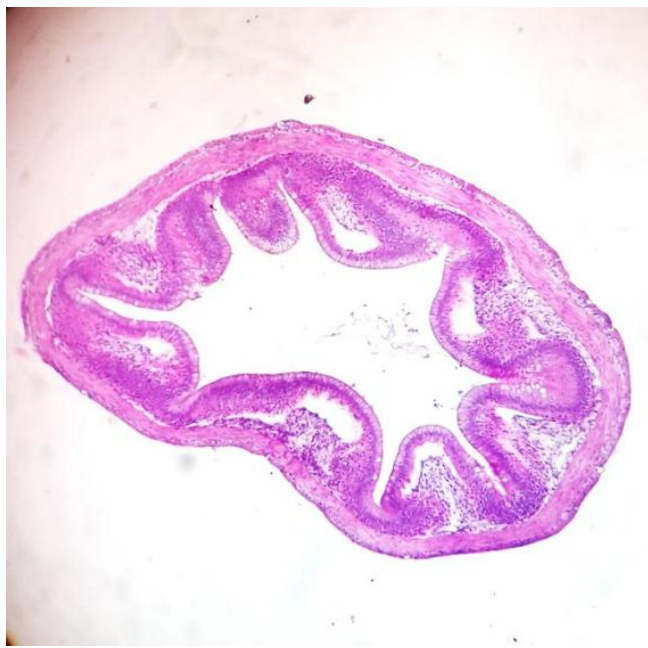

$\mathbf{a}$

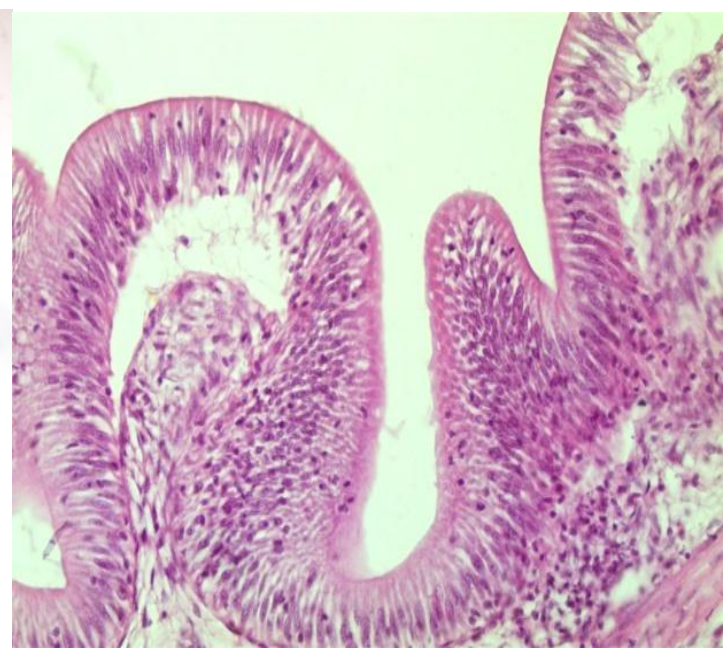

b 


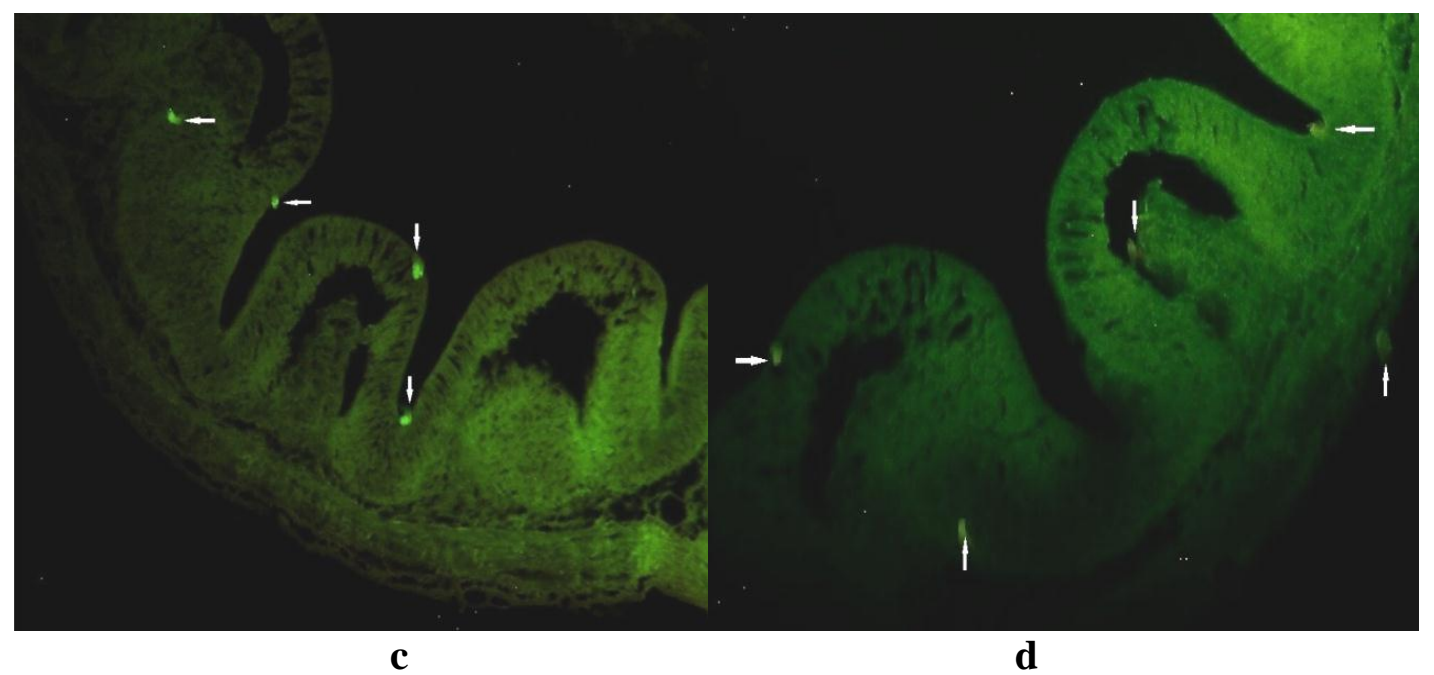

Figure 3: (a) and (b) Photomicrograph showing histological section of fish intestine fed on Diet 1 showing normal architecture $(\times 100$ and $\times 400)$

(c) and (d) Location of probiotics in transverse sections of gastrointestinal tract marked with antibodies to Aneurinibacillus aneurinilyticus, in the villi, microvilli and in the gut lumen (*arrow indicates the immunolabelling positive. To highlight marking, a dark filter was used in these images $)(\times 400)$.

\section{DISCUSSION}

Dietary manipulations with the incorporation and supplementation of different natural ingredients have been proved to enhance growth and immunity and have become the priority for sustainable aquaculture. Probiotics have grabbed incredible consideration for its commitment as a non-traditional source in the aquaculture for giving different wellbeing and growth benefits. Various studies have reported the existence of numerous probiotic bacterial strains in the fish gut that can be incorporated to the diet for enhanced growth and development purposes (Bairagi et al., 2002; Bondad-Reantaso et al., 2005; Balcazar et al., 2006; Kesarcodi-Watson et al., 2008; Bhatnagar and Khandelwal, 2009; Daniels et al., 2010; Bisht et al., 2012; Bhatnagar and Raparia, 2014; Bhatnagar and Lamba, 2017; Bhatnagar and Dhillon, 2019). The present scrutinization with the principal endeavour was led for assessing the colonization and permanence of probiotic enhancing intestinal enzyme activity and immune response, in the terms of blood cell count and respiratory burst activity. Zero mortality revealed no negative impact of the isolated strains on the fingerlings and clearly demonstrated their utilization to be safe. The evaluation of the presence and activity of intestinal enzymes might be utilized as a marker of growth and development of fish, acceptability towards the feed offered and an indicator of their future survival (Cara et al., 2003). It is notable that the intestinal enzymatic activity can denote the acceptance and digestive efficacy of feed offered to the fingerlings (Uberschar, 1993; Hakim et al., 2006).

Probiotics have been recognized to improve the nourishment by fabricating some vitamins, fatty acids, amylase, protease and by detoxifying the conceivably detrimental constituents in the diet (Gatesoupe, 1999). Significant $(p<0.05)$ high digestive enzymatic activities were reported in the Diet 1 fed fingerlings (containing Aneurinibacillus 
aneurinilyticus) than the other dietary groups. High enzymatic activities may be accredited to the presence of probiotics in the feed that colonized in the gut of the fish in the present investigation. Exogenous and extracellular production of protease, amylase and cellulase enzymes by Bacillus has been divulged by distinctive investigations (Bairagi et al., 2004; Rani et al., 2004; Sudesh, 2008). The upgraded nutrient and enzyme supplementation by probiotic prompted expanded food assimilation and retention which thus persuaded better fish growth. Moreover A. aneurinilyticus belonging to class Bacilli is a gram-positive, endospore forming bacteria with thiamine degrading activity for enhanced utilization of the feed. Significant enzymatic activity have been reported by gastrointestinal isolated bacteria such as cellulytic activity in rohu, tilapia, catla, mrigal, grass carp (Ghosh et al., 2002; Saha et al., 2006; Ray et al., 2010; Jiang et al., 2011); amylolytic in grass carp, rohu, murrel, bata (Das and Tripathi, 1991; Kar and Ghosh, 2008; Mondal et al., 2010); proteolytic in salmon (Morita et al., 1998; Askarian et al., 2012); and lipolytic in atlantic cod (Askarian et al., 2013). The contribution of intestinal enzymes to the digestion empowered by gut bacteria show their capacity to help in the assimilation of plant feedstuffs concluding in better growth execution.

Blood corpuscles exemplifies the wellbeing of the organism attributable to immune response. The probiotic supplemented experimental diets showed a significant effect on the erythrocyte and leucocyte count. Verschuere et al. (2000) defined immunostimulants as immune response activating chemicals that delineates more resistance against pathogens. Probiotics have the ability to produce such substances that alert the immune system against pathogen agents (Aguirre-Guzman et al., 2012). The commenced study concedes that probiotic's inclusion significantly enhanced erythrocytes and leucocytes count as to the control group without probiotics. Later on, challenging the experiments fingerlings with pathogenic bacteria $A$. hydrophila, a decrease in erythrocytes and an increase in leucocytes were observed displaying positive immune response in the fingerlings fed with probiotics. Augmented immunity and combat to challenge trial with potent fish pathogen A. hydrophila were observed in all the probiotic incorporated groups while significant $(p<0.05)$ high value of these immunity parameters coincided with Diet 1 fed group in which significant weight gain and enzymatic activities were also observed. Leucocytes have the ability to derive their bactericidal power from a vast range of cellular functions, including phagocytosis. It was perceived that Diet 1 fed fingerlings showed significant $(\mathrm{p}<0.05)$ high number of phagocytic cells revealing to high phagocytic ratio and phagocytic index than the other dietary groups. This may be appertained to the point that the probiotics included in the diet elicited an immune response that defended the body of host on acquaintance to the disease-causing pathogens. Similar has been observed in C. catla (Bhatnagar and Raparia 2014), $C$. mrigala (Bhatnagar and Lamba, 2015; 2017) depicting a possible effective response mediated by leucocyte against pathogenic bacteria, A. hydrophila. Phagocytes illustrate respiratory burst activity while attacking the intrusive pathogens which can be assessed by nitro blue tetrazolium (NBT) assay portraying host defence capabilities. Significantly $(p<0.05)$ high value of NBT was depicted by Diet 1 fed group. Comparative patterns were seen in phagocytosis and free-radical production with the dietary supplementation of probiotic supporting the result of the current work (Kumar et al., 2008; Harikrishanan et al., 2010; Giri et al., 2013; Bhatnagar and Lamba, 2017; Bhatnagar and Dhillon, 2019). 
The colonization and persistence of the probiotic in the host actuate its adequacy. The results of the immunohistochemistry done for the intestine of Diet 1 fed juveniles affirmed the existence and placement of the probiotic supplemented with its binding with anti-Bacillus antibody indicating affirmative markings in the intestinal lumen and microvilli of L. calbasu. Bengmark (1998) and Sansawat and Thirabunyanon (2009) stated the ability of bacterial stain to form colony and tolerate colonization only with its symbiotic bacteria. The autoaggregation and co-aggregation ability exhibited by the probiotics used in the present studies justify it to initiate a strong host protective mechanism in fish gut by colonizing to the intestinal surfaces (Bhatnagar and Dhillon, 2019). Makridis et al. (2001) and Dosta et al. (2012) showed similar presence of the bacterial strain incorporated in the diet with immunohistochemical techniques which were in agreement with the present work. Significant results observed in Diet 1 fed group are attributable to the presence of probiotic related to Bacilli class that provides positive physiological and biological changes in the gut of the fish. The colonization and adherence owing to greater hydrophobicity, aggregation and co-aggregation parameters shown by the isolated strain $A$. aneurinilyticus (Bhatnagar and Dhillon, 2019). Growth performance was significantly high in the group fed on A. aneurinilyticus supplemented diets than those containing Stenotrophomonas sp., and both A. aneurinilyticus and Stenotrophomonas sp. This may be due to the competition between both the bacterial strains for colonizing and adhering in the gut of the fingerlings. Moreover, $A$. aneurinilyticus belonging to Class Bacilli is an endospore forming gram positive aerobic rod-shaped bacteria, which are resistant to chemical and physical agents while Stenotrophomonas sp. belonging to family Gammaproteobacteria do not produce any endospore which makes it less resistant and thus conferring low growth and immunity to the fish when incorporated as dietary supplement. This clearly reveals that the autochthonous probiotic $A$. aneurinilyticus proved to enhance weight, intestinal enzymatic activity and immune response against the pathogenic bacteria in terms of respiratory burst activity, when incorporated in the diet providing a gnotobiotic approach towards sustainable aquaculture.

\section{CONCLUSION}

Aquaculture is assuming utmost importance in satisfying the developing interest for the sustenance of consistently expanding human populace by providing opportunities for the production of wide varieties of aquatic foods including fish and shellfish. The presented gnotobiotic approach of utilizing autochthonous probiotic bacterial strain for proving immunity and better growth performance is a suitable appeal for the administration and implementation of the assets beneficially. The results of the present work may further provide assistance in the prevention of disease risk and growth enhancement which further may lead to the elimination of ineffective chemical substances, immoderate and extravagant immunostimulants. 


\section{REFERENCES}

Aguirre-Guzman, G.; Lara-Flores, M.; Sanchez-Martinez, J.G.; Campa-Cordova, A.I. and Luna-Gonzalez, A. (2012). The use of probiotics in aquatic organisms: A review. Afr. J. Microbiol. Res., 6(23): 4845-4857.

Anderson, D.P. and Siwicki, A.K. (1995). Basic haematology and serology for fish health programs. In: "Diseases in Asian Aquaculture II." Shariff, J.R. and Subasinghe, R.P (Eds.). Philippines Fish Health Section, Asian Fisheries Society, Manila, Philippines, 185pp.

Askarian, F.; Sperstad, S.; Merrifield, D.L.; Ray, A.K. and Ringo, E. (2013). The effect of different feeding regimes on enzyme activity of Atlantic cod (Gadus morhua L.) gut microbiota. Aquac. Res., 44(5): 841-846.

Askarian, F.; Zhou, Z.; Olsen, R.E.; Sperstad, S. and Ringo, E. (2012). Culturable autochthonous bacteria in Atlantic salmon (Salmo salar L.) fed diets with or without chitin. Characterization by $16 \mathrm{~S}$ rRNA gene sequencing, ability to produce enzymes and in vitro growth inhibition of four fish pathogens. Aquaculture, 326: $1-8$.

Austin, B.; Stuckey, L.F.; Robertson, P.A.W.; Effendi, I. and Griffith, D.R.W. (1995). A probiotic strain of Vibrio alginolyticus effective in reducing diseases caused by Aeromonas salmonicida, Vibrio anguillarum and Vibrio ordalii. J. Fish Dis., 18(1): 93-96.

Bairagi, A.;Sarkar Ghosh, K.; Sen, S.K. and Ray, A.K. (2002). Duckweed (Lemna polyrrhiza) leaf meal as source of feedstuff in formulated diets for rohu (Labeo rohita) fingerlings after formulation with a fish intestinal bacterium. Bioresour. Technol., 85(1): 17-23.

Bairagi, A.; Sarkar Ghosh, K.; Sen, S.K. and Ray, A.K. (2004). Evaluation of the nutritive value of Leucaena leucocephala leaf meal, inoculated with fish intestinal bacteria Bacillus subtilis and Bacillus circulans in formulated diets for rohu, Labeo rohita (Hamilton) fingerlings. Aquac. Res., 35(5): 36-446.

Balcazar, J.L.; Vendrell, D.; De Blas, I.; Ruiz-Zarzuela, I.; Girones, O. and Muzquiz, J.L. (2006). Immune modulation by probiotic strains: quantification of phagocytosis of Aeromonas salmonicida by leukocytes isolated from gut of rainbow trout (Oncorhynchus mykiss) using a radio labelling assay. Comp. Immunol. Microbiol. Infect. Dis., 29(5-6): 335-343.

Bengmark, S. (1998). Probiotics and prebiotics in prevention and treatment of gastrointestinal diseases. Gastroenterol. Int., 11: 4-7.

Bhatnagar, A. and Dhillon, O. (2019). Characterization, screening and application of bacteria with probiotic adequacy isolated from the gut of Labeo calbasu (Hamilton, 1822). Fish. Aquat. Life., 27: 178-189.

Bhatnagar, A. and Khandelwal, S. (2009). Gut adherent potential probiotic bacteria in feeds for Catla catla for sustainable aquaculture. In: National Conference on Advances in Biological Sciences, Panjab University, Chandigarh, pp. 8.

Bhatnagar, A. and Lamba, R. (2015). Antimicrobial ability and growth promoting effects of feed supplemented with probiotic bacterium isolated from gut microflora of Cirrhinus mrigala. J. Integr. Agric., 14(3): 583-592. 
Bhatnagar, A. and Lamba, R. (2017). Molecular Characterization and Dosage Application of Autochthonous Potential Probiotic Bacteria in Cirrhinus mrigala. J. FisheriesSciences.com., 11(2): 046-056

Bhatnagar, A. and Raparia, S. (2014). Optimum dietary inclusion level of Bacillus coagulans for growth and digestibility improvement for Catla catla (Hamilton). Int. J. Curr. Res. Rev., 6(7): 1-10.

Bisht, A.; Singh, U.P. and Pandey, N.N. (2012). Bacillus subtilis as a potent probiotic for enhancing growth in fingerlings of common carp (Cyprinus carpio L.) Indian J. Fish 59(3): 103-108.

Bondad-Reantaso, M.G.; Subasinghe, R.P.; Arthur, J.R.; Ogawa, K.; Chinabut, S.; Adlard, R.; Tan, Z. and Shariff, M. (2005). Disease and health management in Asian aquaculture. Vet. Parasitol., 132: 249-272.

Cara, J. B.; Moyano, F.J.; Cardenas, S.; Fernandez-Diaz, C. and Yufera, M. (2003). Assessment of digestive enzyme activities during larval development of white bream. J. Fish Biol., 63(1): 48-58.

Carnevali, O.D.; Sulpizio, L.; Gioacchini, R.; Olivotto, I.G. and Silvi, S. (2006). Growth improvement by probiotic in European sea brass juveniles (Dicentrachus labrax, L.) with particular attention to IGF-1, myostatin and cortisol gene expression. Aquaculture, 258: 430-438.

Christian, B.A. (2007). Understanding Food: Principles and Preparation, third ed. Cengage Learning, pp. 546.

Coconnier M.H.; Bernet M.F.; Kerneis S.; Chauviere G.; Fourniat J. and Servin A.L. (2003). Inhibition of adhesion of entero invasive pathogens to human intestinal Caco-2 cells by Lactobacillus acidophilus strain LB decreases bacterial invasion. FEMS Microbiol. Lett., 110: 299-306.

Dacie, S.I.V. and Lewis, S.M. (1971). Practical Haematology, J and A Churchill Ltd., Livington, London, Melbourne and New York.

Daniels, C.L.; Merrifield, D.L.; Boothroyd, D.P.; Davies, S.J.; Factor, J.R. and Arnold, K.E. (2010). Effect of dietary Bacillus sp. and mannan oligosaccharides (MOS) on European lobster (Homarus gammarus L.) larvae growth performance, gut morphology and gut microbiota. Aquaculture, 304: 49-57.

Das, K.M. and Tripathi, S.D. (1991). Studies on the digestive enzymes of grass carp, Ctenopharyngodon idella (Val.). Aquaculture, 92: 21-32.

Dosta, M.D.C.M.; Barrera, T.C.; Perrino, F.J.F.; Reyes, L.M.; Gutierrez, H.H. and Suarez, S.C. (2012). Bacteria with probiotic capabilities isolated from the digestive tract of the ornamental fish Pterophyllum scalare. In: "Probiotic in Animals. InTech."

Duncan, D.B. (1955). Multiple range and Multiple F Tests. Biometrics, 11(1): 1-42.

Garg, S.K.; Kalla, A. and Bhatnagar, A. (2002). Evaluation of raw and hydrothermically processed leguminous seeds as supplementary feed for the growth of two Indian major carps. Aquac. Res., 10: 87-107.

Gatesoupe, F.J. (1999). The use of probiotics in aquaculture. Aquaculture, 180: 147-165.

Ghosh, K.; Sen, S.K. and Ray, A.K. (2002). Characterization of Bacilli isolated from gut of rohu, Labeo rohita, fingerlings and its significance in digestion. J. Appl. Aquaculture, 12(3): 33- 42. 
Giri, S.S.; Sukumaran, V. and Oviva, M. (2013). Potential probiotic Lactobacillus plantarum VSG-3 improves the growth, immunity, and disease resistance of tropical freshwater fish, Labeo rohita. Fish Shellfish Immun., 34(2): 660-666.

Hakim, Y.; Uni, Z.; Hulata, G. and Harpaz, S. (2006). Relationship between intestinal brush border enzymatic activity and growth rate in tilapias fed diets containing $30 \%$ or $48 \%$ protein. Aquaculture, 257(1-4): 420-428.

Harikrishnan, R.; Balasundaram, C. and Heo, M.S. (2010). Effect of probiotics enriched diet on Paralichthys olivaceus infected with lymphocystis disease virus (LCDV). Fish Shellfish Immun., 29(5): 868-874.

Jiang, Y., Xie, C., Yang, G., Gong, X., Chen, X., Xu, L. and Bao, B. (2011). Cellulase producing bacteria of Aeromonas are dominant and indigenous in the gut of Ctenopharyngodon idellus (Valenciennes). Aquac. Res., 42: 499-505.

Kar, N. and Ghosh, K. (2008). Enzyme producing bacteria in the gastrointestinal tracts of Labeo rohita (Hamilton) and Channa punctatus (Bloch). Turk. J. Fish. Aquat. Sc., 8: 115-120.

Kesarcodi-Watson, A.; Kaspar, H.; Lategan, M.J. and Gibson, L. (2008). Probiotics in aquaculture: the need, principles and mechanisms of action and screening processes. Aquaculture, 74: 1-14.

Kumar, R.; Mukherjee, S.C.; Ranjan, R. and Nayak, S.K. (2008). Enhanced innate immune parameters in Labeo rohita (Ham.) following oral administration of Bacillus subtilis. Fish Shellfish Immun., 24(2): 168-172.

Makridis, P.; Bergh, O.; Skjermo, J. and Vadstein, O. (2001). Addition of bacteria bioencapsulated in Artemia metanauplii to a rearing system for halibut larvae. Aquacult. Int., 9: 225-235.

Mondal, S.; Roy, T. and Ray, A.K. (2010). Characterization and identification of enzyme producing bacteria isolated from the digestive tract of bata, Labeo bata. J. World Aquacult. Soc., 41: 369-376.

Morita, Y.; Hasan, Q.; Sakaguchi, T.; Murakami, Y.; Yokoyama, K. and Tamiya, E. (1998). Properties of a cold-active protease from psychrotrophic Flavobacterium balustinum P104. Appl. Microbiol. Biotechnol., 50: 669-675.

Park, K.H. and Jeong, H.D. (1996). Enhanced resistance against Edwardsiella tarda infection in tilapia Oreochromis niloticus by administration of protein bound polysaccharide. Aquaculture, 141: 135-143.

Pearse, A.G.E. (1968). Common cytochemical and ultrastructural characteristics of cells producing polypeptide hormones (the APUD series) and their relevance to thyroid and ultimobranchial C cells and calcitonin. Proc. Royal Soc. B., 170(1018): 7180.

Rani, S.R.; Garg, S.K.; Sabhlok, V.P. and Bhatnagar, A. (2004). Intestinal enzyme activity and enzyme producing microbial flora in relation to feeding behavior in some brackish water teleost. Aquaculture, 12: 55-68.

Ray, A.K.; Roy, T.; Mondal, S. and Ringo, E. (2010). Identification of gut-associated amylase, cellulase and protease-producing bacteria in three species of Indian major carps. Aquac. Res., 41: 1462-1469.

Sadasivam, S. and Manickam, A. (1996). Biochemical methods, second ed. New Age International Publishers. 
Saha, S.; Roy, R.N.; Sen, S.K. and Ray, A.K. (2006). Characterization of cellulaseproducing bacteria from the digestive tract of tilapia, Oreochromis mossambica (Peters) and grass carp, Ctenopharyngodon idella (Valenciennes). Aquac. Res., 37: 380-388.

Salinas, I.; Myklebust, R.; Esteban, M.A.; Olsen, R.E.; Meseguer, J. and Ringo, E. (2008). In vitro studies of Lactobacillus delbrueckii subsp. Lactis in Atlantic salmon (Salmo salar L.) foregut: tissue responses and evidence of protection against Aeromonas salmonicida subsp.salmonicida epithelial damage. Vet. Microbiol., 128: 167-177.

Sansawat, A. and Thirabunyanon, M. (2009). Anti-Aeromonas hydrophila activity and characterisation of novel probiotic strains of Bacillus subtilis isolated from the gastrointestinal tract of giant freshwater prawns. Maejo Int. J. Sci. Tec., 3(1): 7787.

Sawhney, S.K. and Singh, R. (2000). Introductory Practical Biochemistry. Narosa Publishing House, pp. 452.

Siwicki, A.K.; Anderson, D.P. and Rumsey, G.L. (1994). Dietary intake of immunostimulants by rainbow trout affects non-specific immunity and protection against furuncuclosis. Vet. Immunol. Immunopathol., 41: 125-139.

Son, V.M.; Chang, C.C.; Wu, M.C.; Guu, Y.K.;Chiu, C.H. and Cheng, W. (2009). Dietary administration of the probiotic, Lactobacillus plantarum, enhanced the growth, innate immune responses, and disease resistance of the grouper Epinephelus coioides. Fish Shellfish Immunol., 26(5): 691-698.

Sudesh (2008). Studies on enzyme producing microflora and potential probiotic bacteria from the gut of Catla catla (Hamilton). M. Phil. Dissertation, Kurukshetra University, Kurukshetra, Haryana, India.

Uberschar, B. (1993). Measurement of proteolytic enzyme activity: Significance and application in larval fish research. Physiological and Biochemical Aspects of Fish Development, pp. 233-239.

Verschuere, L.; Rombaut, G.; Sorgeloos, P. and Verstraete, W. (2000). Probiotic bacteria asbiological control agents in aquaculture. Microbiol. Mol. Biol. R., 64: 655-671.

Vine, N.G.; Leukes, W.D.; Kaiser, H.; Daya, S.; Baxter, J. and Hecht, T. (2004). Competition for attachment of aquaculture candidate probiotic and pathogenic bacteria on fish intestinal mucus. J. Fish Dis., 27: 319-26.

Walter, H.E. (1984). Probionases: Methods with haemoglobin, casein and azocoll as substrates. In: "Methods of Enzymatic Analysis." Bergmeyer, H.U. (Ed.), pp. 270-277.

Wang, Y.B.; Li, J.R. and Lin, J. (2008). Probiotics in aquaculture: challenges and outlook. Aquaculture, 281(1-4): 1-4. 